\title{
STUDY OF MICROBIAL POLYSACCHARIDES' IMPACT ON ORGANOLEPTIC AND PHYSICAL-CHEMICAL PARAMETERS OF PROTEIN-FREE AND GLUTEN-FREE FLOURY PRODUCTS
}

\author{
Valerii Mykhaylov \\ Department of Processes, Devices and Automation of Food Production ${ }^{1}$ \\ v.mykhailov.@hduht.edu.ua \\ Olga Samokhvalova \\ Department of Bakery, Confectionary, Pasta and Food Concentrates Technology ${ }^{l}$ \\ sam55ov@gmail.com \\ Zinoviya Kucheruk \\ Department of Bakery, Confectionary, Pasta and Food Concentrates Technology ${ }^{1}$ \\ kzinoviya2703@gmail.com \\ Kateryna Kasabova \\ Department of Technology of Bakery, Confectionary, Pasta and Food Concentrates ${ }^{1}$ \\ Kasabova_kateryna@hduht.edu.ua \\ Olga Simakova ${ }^{2}$ \\ SimakovaO@donnuet.edu.ua \\ Iuliia Goriainova ${ }^{2}$ \\ goryaynova_@donnuet.edu.ua \\ Alla Rogovaya \\ rsi1.@ukr.net \\ Inna Choni \\ inna.choni@gmail.com \\ ${ }^{1}$ Kharkiv State University of Food Technology and Trade \\ 333 Klochkivska str., Kharkiv, Ukraine, 61051 \\ ${ }^{2}$ Department of technology in a restaurant economy that hotel and restaurant business \\ Donetsk National University of Economics and Trade named after MykhailoTugan-Baranovsky \\ 16 Tramvaina str., Kryvyi Rih, Ukraine, 50005 \\ ${ }^{3}$ Food Production Technology and restaurants chair \\ Poltava University of Economics and Trade \\ 3 Kowalja str., Poltava, Ukraine, 36000
}

\footnotetext{
Abstract

The aim of the study is to investigate the influence of microbial polysaccharides (MPS): xampan, enposan and gellan on quality parameters of protein-free and gluten-free floury products that will widen the assortment of stiffeners of the microbial origin in technologies of gluten-free products.

The formation of the required quality indicators of gluten-free dietary bakery and floury confectionery, which should be made without wheat flour, is difficult due to the lack of gluten. The search for effective structure-forming agents in place of gluten proteins is ongoing. Properties of microbial polysaccharides are considered and the possibility of their use for gluten-free products is investigated. The influence of microbial polysaccharides (MPS) of xanthan, enposan and gellan on the organoleptic parameters of protein-free bread, based on corn starch and gluten-free muffins, based on wheat germ meal was investigated. Their specific volume is determined. The structural-mechanical properties of bread crumbs and muffins on an automated penetrometer in terms of compressibility are determined.
} 
It is shown, that the use of MPS in certain quantities leads to the formation of susceptible organoleptic characteristics, increases the specific volume of products and ensure the elastic structure of the baked goods. All the investigated MPS have the same character of influence on certain indicators, but the greatest effect is revealed by xanthan, the least - by gellan.

Keywords: microbial polysaccharides, protein-free bread, gluten-free muffins, organoleptic characteristics, structural and mechanical properties of crumbs, specific volume.

DOI: $10.21303 / 2504-5695.2019 .001067$

\section{Introduction}

For making dietary protein-free and gluten-free and healthy products, the main condition is to exclude wheat flour as a source of "problem" food proteins.

As it is demonstrated in works [1,2], gluten replacement is a serious technological problem, because it plays a main role in the structure formation of dough and baked products. It is most difficult from the technological point of view to get necessary parameters of protein-free bread, comparing with other products, because dietary requirements sternly limit protein and exclude all ingredients with its high content.

Studies [3-5] proved that an improvement of structural-mechanical characteristics of dough and baked products may take place at the expanse of selecting stiffeners and gel-formers that play a role of main structure-formers in gluten-free systems. Such stiffeners as pectin, carboxymethyl cellulose, agar, guar gum, xanthan essentially influence main properties of dough, based on rice flour, rice, corn and other starches and quality parameters of ready products.

A variant of overcoming difficulties of structure formation of gluten-free dough systems may be optimization of a quality content of structure-formers. Just in 2007 [6] compared different types of stiffeners and demonstrated that the presence of different hydrocolloids, such as hydroxypropyl methylcellulose (HPMC), carboxymethyl cellulose (CMC), plantain gum, carob tree fruits, guar gum and xanthan favors an increase of resistance to deformation and elasticity of gluten-free dough. It has been proved, that xanthan has the most influence on viscous-firm properties of dough that condition its strengthening. There has been established a line of the positive influence of stiffeners on the dough structure: $x$ anthan $>C M C>$ pectin $>$ agar $>\beta$-glucan.

The most important factor of structure formation of protein-free and gluten-free products is, from our point of view, the use of hydrocolloids of different nature with substantiating their quantity ratio.

Xanthan (E 415) (other names: xampan, xanthan gum) is considered as the most effective stiffener of the microbiological origin; work [7] accents that it is a key ingredient in the structure formation of products without gluten.

But there are, and appeared at the market recently also other microbial polysaccharides, that due to their construction and properties may be used in the technology of protein-free and gluten-free products. They include enposan and gellan. Despite the fact that information about enposan properties appeared long ago [9], there are not enough studies about its use in gluten-free and protein-free products. Gellan (E 418) has a status of food supplement and is used as a stiffener and gel-former in food industry; alongside with it there are no systematized data about its influence on properties of gluten-free products. Their main characteristics together with xanthan are presented in Table $\mathbf{1}$.

Although enposan and gellan have properties and construction, similar to xampan, their technological potential as to the influence on organoleptic and physical-chemical parameters of products is not fully estimated, especially in gluten-free dough systems.

The aim of the study is to investigate the influence of microbial polysaccharides (MPS): xampan, enposan and gellan of quality parameters of protein-free and gluten-free floury products that will widen the assortment of stiffeners of the microbial origin in technologies of gluten-free products.

The following tasks were set for attaining this aim:

- to study the influence of xampan, enposan and gellan (MPS) on organoleptic parameters of products;

- to study the influence of MPS on structural-mechanical properties of products' crumb and specific volume. 
Table 1

Characteristics of xanthan, enposan and gellan

\begin{tabular}{|c|c|c|}
\hline $\begin{array}{c}\text { Polysaccharide } \\
\text { producer }\end{array}$ & Molecular construction, molecular mass & Physical-chemical properties and use \\
\hline $\begin{array}{l}\text { Xanthan } \\
\text { Xanthomonas } \\
\text { campestris }\end{array}$ & $\begin{array}{c}\text { Heteropolysaccharide, consisted of } \\
\beta \text {-D-mannose, } \beta \text {-D-glucuronic acid and } \\
\alpha \text {-D-mannose. } \\
\text { Molecular mass } 1000-2000 \mathrm{kDa}\end{array}$ & $\begin{array}{l}\text { Extracellular heteropolysaccharide. Remains of glucuronic acid } \\
\text { and acid grapevine group add the anion character to its mole- } \\
\text { cules. It forms rather viscous water solutions at the small con- } \\
\text { centration. Viscosity of solutions almost doesn't depend on the } \\
\text { influence of pH value of a medium. It demonstrates the viscosity } \\
\text { stability of solutions at changing ionic force, heating or freezing, } \\
\text { effect of enzymes, chemical substances. The process of jelly for- } \\
\text { mation is possible at using it with separate galactomannans that } \\
\text { synergism is observed with [8]. }\end{array}$ \\
\hline $\begin{array}{l}\text { Enposan } \\
\text { (polymixan) } \\
\text { Bacillus polymyxa }\end{array}$ & $\begin{array}{l}\text { Heteropolysaccharide, consisted of } \\
\text { D-glucose, D-mannose, D-galactose and } \\
\text { D- galacturonic acid. Molecular mass } \\
1000-2000 \mathrm{kDa}\end{array}$ & $\begin{array}{l}\text { Polymixan is very similar to xanthan by its physical-chemical } \\
\text { properties. It is used as a stiffener and stabilizer in many indus- } \\
\text { trial branches [9]. }\end{array}$ \\
\hline $\begin{array}{c}\text { Gellan } \\
\text { Sphingomonas } \\
\text { Elodea (earlier } \\
\text { Pseudomonas } \\
\text { elodea) }\end{array}$ & $\begin{array}{l}\text { Heteropolysaccharide of the linear } \\
\text { construction, which molecules consist of } \\
\text { iterative tetrasaccharide pyranose rings of } \\
\text { 1.3- } \beta \text {,D-glucose, } 1.4-\beta, \mathrm{D} \text {-glucuronic acid, } \\
\text { 1.4- } \beta, \mathrm{D} \text {-glucose and } 1.4-\alpha, \mathrm{L}-\text {-rhamnose. } \\
\text { Molecular mass is near } \\
500 \mathrm{kDa}\end{array}$ & $\begin{array}{l}\text { It has jelling, stabilizing and film-forming properties. Forms } \\
\text { jellies with almost all ions, but demonstrates relationship with } \\
\text { bivalent ions, much stronger than with monovalent ones. Bivalent } \\
\text { ions of calcium and magnesium provide the optimal firmness of } \\
\text { gellan jellies, stable to the temperature influence and enzyme } \\
\text { effect, stable in pH diapason } 3.5 . . .8 .0,[10] \text {. }\end{array}$ \\
\hline
\end{tabular}

\section{Materials and methods}

Microbial polysaccharides: xampan - TC U 88-105-001-2000 and enposan - TC U 6420100488.001 - made by "Enzifarm”, Ukraine, and also gellan, made by «CP Kelco ApS», Denmark were used in the research.

Protein-free bread was produced by the following recipe ratio of components: corn starch -100.0 , peeled rye flour -5.0 , kitchen salt -2.5 , sugar -4.0 , sunflower oil - 5.0, dry yeast -0.8 and MPS - 0.3 , water - by the calculation for dough humidity $49 \%$; bread, prepared by this recipe without adding MPS was a control.

Gluten-free muffins were prepared of components in the following weight ratios: wheat germ meal - 37.0, white sugar -18.0 , margarine -17.0 , chicken eggs -8.0 , kefir -18.0 , vanilla sugar - 1.0, fluffer -0.2 , salt -0.5 and MPS $-0.1 \ldots 0.3$; two control samples were used. Control No. 1 - products, obtained, using wheat flour without supplements, and control No. 2 - products with using wheat germ meal without experimental supplements.

Organoleptic parameters of the baked products were determined by assessment criteria of products' quality by test laboratory baking in 6 hours after baking [11].

Structural-mechanical properties of products' crumb were determined by the conventional method by a compressibility parameter on the automated penetrometer AP-4/2, made by "Finemass", Germany [11].

The specific volume of samples of the baked products was calculated by the formula

$$
V_{\text {spec }}=V / m, \mathrm{~cm}^{3} / \mathrm{g}
$$

where $V$ - sample volume, $\mathrm{cm}^{3}, \mathrm{~m}$ - sample mass, $\mathrm{g}$.

The samples' volume was determined by the conventional method on the special device (volume measurer) that functions by the principles of powdery filler displacing by bread. Millet was used as the powdery filler [11].

The error value for all studies was $\sigma=3 \ldots . .5 \%$, number of iterations of the experiments $-n=3$, probability $-P \geq 0.95$. 


\section{1. Experiments}

It has been demonstrated, that the use of xanthan, enposan and gellan in amount $0.3 \%$ of the starch mass provides formation of the needed dough structure for protein-free bread, prepared by the aforesaid ratio of recipe components.

The organoleptic parameters of such baked protein-free bread are presented in Table 2, and its outlook on Fig. 1.

Table 2

The organoleptic parameters of protein-free bread with using microbial polysaccharides

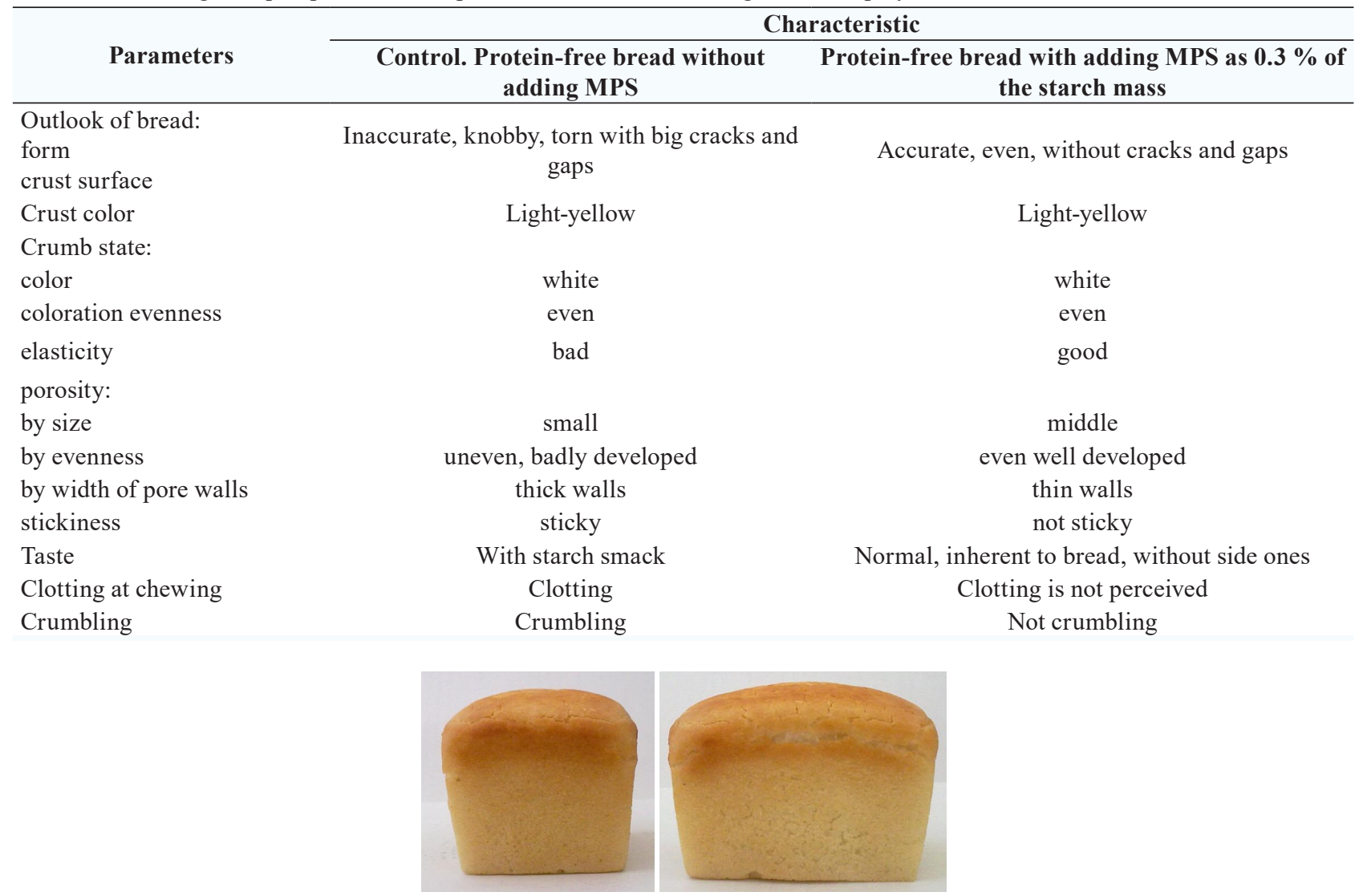

Fig. 1. Outlook of the experimental sample of formed protein-free bread from two sides

Photos of crumb of bread, baked with adding microbial polysaccharides are presented on

Fig. 2. The photos are made by the method of microscoping at 10 times magnification.

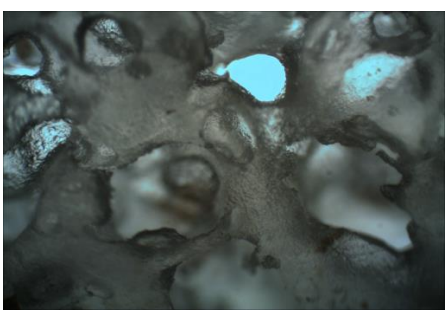

$a$

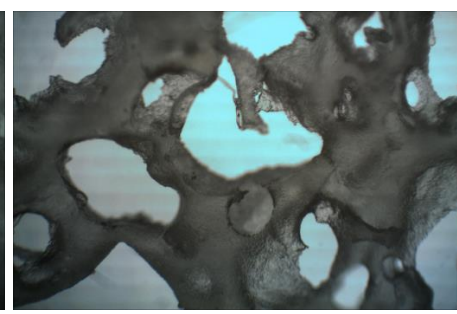

$b$

Fig. 2. Photos of the crumb structure of protein-free bread under the microscope $(\times 10)$ : $a$ - control; $b$ - experimental sample.

The results of studying the influence of microbial polysaccharides on physical-chemical parameters of baked protein-free bread are presented in Table 3. 
Table 3

The physical-chemical parameters of protein-free bread with using xanthan, enposan, $n=3, P \geq 0.95, \sigma=3 \ldots 5 \%$

\begin{tabular}{ccccc}
\hline Parameter & $\begin{array}{c}\text { Without supplement } \\
\text { (control) }\end{array}$ & \multicolumn{2}{c}{$\begin{array}{c}\text { Value of the parameter with introducing 0.3 \% of MPS of } \\
\text { the starch mass }\end{array}$} \\
\cline { 3 - 5 } & 40 & xanthan & enposan & gellan \\
\hline $\begin{array}{c}\text { Compressibility of crumb on } \\
\text { the penetrometer, device units } \\
\text { Specific volume, } \mathrm{cm}^{3} / \mathrm{g}\end{array}$ & 1.8 & 58 & 54 & 50 \\
\end{tabular}

The use of microbial polysaccharides as structure-formers in gluten-free floury confectionary products was substantiated on the example of muffins. Wheat germ meal (WBM) was used in recipes of muffins as gluten-free flour.

This meal forms after extraction of germ oil by ethyl alcohol and differs by the high content of proteins and carbohydrates. Carbohydrates are presented in almost $60.0 \%$ by the complex of polysaccharides that belong to dietary fiber (cellulose, hemicelluloses, lignin and pectin substances). That is why meal is considered as an effective improver by protein and dietary fiber. It also contains vitamins of B group, vitamin E, PP, carotenoids and mineral substances. At that meal is produced in Ukraine, and its production favors solving questions of complete processing of raw materials in Ukraine. At the complete replacement of wheat flour by WBM there takes place the maximal use of the improving supplement.

It is demonstrated, that the use of WBM in amount $0.1 \%$ of the product mass in dough for muffins provides the formation of needed rheological properties of dough that may be formed by the method of transplanting. The research results of the influence of the aforesaid amount of MPS on the organoleptic parameters of the baked gluten-free muffins are presented in Table 4, and their outlook in cut - on Fig. 3.

Table 4

The organoleptic parameters of muffins with using wheat germ meal

\begin{tabular}{|c|c|c|c|}
\hline \multirow{2}{*}{ Parameter } & \multirow{2}{*}{$\begin{array}{c}\text { Control No. } 1 \\
\text { (without a supplement) }\end{array}$} & \multicolumn{2}{|c|}{ Muffins } \\
\hline & & Wheat germ meal (control No. 2) & Wheat germ meal with MPS \\
\hline Outlook & $\begin{array}{l}\text { Accurate form, } \\
\text { with cracks, without gaps }\end{array}$ & $\begin{array}{l}\text { Accurate form, } \\
\text { with cracks, without gaps }\end{array}$ & $\begin{array}{l}\text { Accurate form, } \\
\text { with cracks, without gaps }\end{array}$ \\
\hline Color & Crust - gold, crumb - light-yellow & \multicolumn{2}{|c|}{ Crust - light-brown, crumb - gold-brown } \\
\hline Smell & $\begin{array}{l}\text { Inherent to products, } \\
\text { without side smells }\end{array}$ & \multicolumn{2}{|c|}{ Pleasant, with brightly expressed nut smell } \\
\hline Taste & $\begin{array}{l}\text { Inherent to products, } \\
\text { without side smacks }\end{array}$ & \multicolumn{2}{|c|}{ Pleasant, full, with brightly expressed nut smack } \\
\hline Crumb state & Soft, well picked & Crumbling, weakly picked & Soft, well picked, elastic \\
\hline
\end{tabular}

The results of studying the influence of microbial polysaccharides on physical-chemical parameters of the baked gluten-free muffins with wheat germ meal are presented in Table 5.

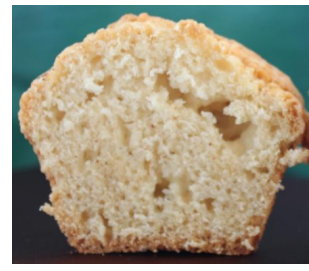

$a$

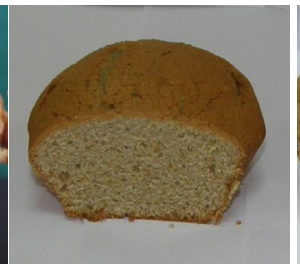

$b$

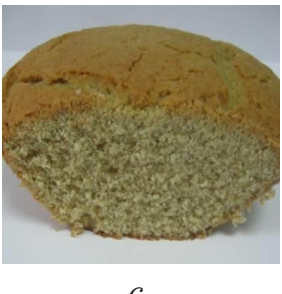

$c$

Fig. 3. Outlook of the muffins in cut: $a$ - control No. 1 (on wheat flour); $b$ - control No. 2 (on wheat germ meal); $c$ - on wheat germ meal with MPS 
Table 5

The quality parameters of muffins with wheat germ meal with using xanthan, enposan, gellan $n=3, P \geq 0.95$, $\sigma=3 \ldots . .5 \%$

\begin{tabular}{ccccc}
\hline \multirow{2}{*}{ Parameter } & Without supple- & & \multicolumn{2}{c}{$\begin{array}{c}\text { Parameter value with adding MPS as 0,1 \% of } \\
\text { the ready product mass }\end{array}$} \\
\cline { 3 - 5 } & ment (control) & xanthan & Enposan & gellan \\
\hline $\begin{array}{c}\text { Crumb compressibility on } \\
\text { the penetrometer, device un. }\end{array}$ & 50 & 60 & 58 & 55 \\
Specific volume, $\mathrm{cm}^{3} / \mathrm{g}$ & 2,8 & 3,2 & 3,1 & 2,9
\end{tabular}

\section{Results}

At adding xanthan, enposan and gellan, there was not revealed an essential difference between them in the influence on the formation of organoleptic parameters of bread. As it is seen on Table 2, products with adding all microbial polysaccharides had the well developed porosity, nonsticky crumb, even surface without cracks and gaps. Bread without MPS had the weakly developed porosity, big cracks on the surface, sticky crumb. It may be stated, that adding microbial polysaccharides favors the formation of the necessary organoleptic parameters. Crumb of protein-free bread was similar to wheat one by them.

The obtained data on the photo (Fig. 1) testify to the formation and fixation of the porous structure of protein-free bread at using microbial polysaccharides.

As it is seen on Table 3, adding MPS in amount $0.3 \%$ of the starch mass increases the specific volume of the products, comparing with the control. The most effect is demonstrated by xanthan - the parameter increases its value by $36 \%$, the least one - by gellan, the parameter increases its value by $33 \%$. The crumb compressibility on the penetrometer improves too that testifies to the elastic crumb structure formation. It is known, that the specific volume of floury products is provided by the ability of gluten and other proteins, included in the dough system, to fix the fluffy structure at baking. Although at adding MPS there takes place the improvement of the products' specific volume and compressibility on the penetrometer, it may be assumed, that swollen microbial polysaccharides together with proteins of other components play the role of gluten in a gluten-free dough system and provide the porous structure formation of these products.

The dough for muffins essentially differs from the protein-free bread dough by structure, it contains more moisture, includes protein-containing milk and egg products that participate in the formation of organoleptic parameters and structure of the gluten-free confectionary product.

The data of Table 4 show that muffins with the complete replacement of wheat flour by wheat germ meal have the pleasant organoleptic quality parameters. But these products have the small volume, not elastic excessively crumbling crumb at the expanse of absence of gluten proteins and starch of wheat flour, responsible for the products' structure formation. The addition of xanthan, enposan and gellan in muffins, based on wheat germ meal, improves the organoleptic parameters of the products. They have the equal influence on these parameters. Muffins with MPS have the perfect outlook, cracks on the surface, typical for these products. The products have soft, elastic crumb, not powdery not crumbling.

As it is seen on Table 5, adding MPS in amount $0.1 \%$ of the ready product mass increases the specific volume of muffins. Thus, at adding xanthan, the specific volume of products increases by $14.3 \%$, ensospan - by $10.7 \%$, gellan - by $3.5 \%$. The crumb compressibility of products increases too. At adding xanthan it increases by $20 \%$, ensopan - by $16 \%$, gellan - by $10 \%$. At that xanthan in gluten-free dough for muffins also demonstrates the most influence, gellan - the least one.

In general it may be said, that MPS participate in the creation and support of the dough structure, in such a way providing the formation of organoleptic and physical-chemical parameters of gluten-free products. 


\section{Conclusions}

1. The addition of microbial polysaccharides favors the creation of the needed organoleptic parameters of protein-free bread, based on corn starch. The products have the well developed porosity, non-sticky crumb, even surface without cracks and gaps. At that the specific volume of the products and structural-mechanical parameters of crumb improve. The formation of the products' porous structure is provided at baking.

2. The use of MPS in gluten-free muffins, based on wheat germ meal, provides the formation of soft, well picked, elastic crumb. At that the specific volume and structural-mechanical parameters of muffin crumb improve.

3. All studied MPS demonstrate the equal type of influence on physical-chemical parameters of products, but the most effect is demonstrated by xanthan, the least one - by gellan.

4. The studies demonstrated the possibility of using enposan and gellan as structure forming raw materials in gluten-free products. But a mechanism of forming the crumb structure of products at baking with the presence of microbial polysaccharides and their influence on the quality preservation at storage remain incompletely studied. So, further studies as to the influence of MPS on organoleptic and physical-chemical parameters of products at storage are promising.

\section{References}

[1] Deora, N. S., Deswal, A., Mishra, H. N. (2014). Alternative Approaches Towards Gluten-Free Dough Development: Recent Trends. Food Engineering Reviews, 6 (3), 89-104. doi: https://doi.org/10.1007/s12393-014-9079-6

[2] Foschia, M., Horstmann, S., Arendt, E. K., Zannini, E. (2016). Nutritional therapy - Facing the gap between coeliac disease and gluten-free food. International Journal of Food Microbiology, 239, 113-124. doi: https://doi.org/10.1016/j.ijfoodmicro. 2016.06.014

[3] Mir, S. A., Shah, M. A., Naik, H. R., Zargar, I. A. (2016). Influence of hydrocolloids on dough handling and technological properties of gluten-free breads. Trends in Food Science \& Technology, 51, 49-57. doi: https://doi.org/10.1016/j.tifs.2016.03.005

[4] Kittisuban, P., Ritthiruangdej, P., Suphantharika, M. (2014). Optimization of hydroxypropylmethylcellulose, yeast $\beta$-glucan, and whey protein levels based on physical properties of gluten-free rice bread using response surface methodology. LWT Food Science and Technology, 57 (2), 738-748. doi: https://doi.org/10.1016/j.lwt.2014.02.045

[5] Crockett, R., Ie, P., Vodovotz, Y. (2011). How Do Xanthan and Hydroxypropyl Methylcellulose Individually Affect the Physicochemical Properties in a Model Gluten-Free Dough? Journal of Food Science, 76 (3), E274-E282. doi: https://doi.org/ 10.1111/j.1750-3841.2011.02088.x

[6] Lazaridou, A., Duta, D., Papageorgiou, M., Belc, N., Biliaderis, C. G. (2007). Effects of hydrocolloids on dough rheology and bread quality parameters in gluten-free formulations. Journal of Food Engineering, 79 (3), 1033-1047. doi: https://doi.org/ 10.1016/j.jfoodeng.2006.03.032

[7] Noorlaila, A., Hasanah, H. N., Asmeda, R., Yusoff, A. (2018). The effects of xanthan gum and hydroxypropylmethylcellulose on physical properties of sponge cakes. Journal of the Saudi Society of Agricultural Sciences. doi: https://oi.org/10.1016/ j.jssas.2018.08.001

[8] Samokhvalova, O., Chernikova, Y., Oliinyk, S., Kasabova, K. (2015). The effect of microbial polysaccharides on the properties of wheat flour. Eastern-European Journal of Enterprise Technologies, 6 (10 (77)), 11-15. doi: https://doi.org/10.15587/17294061.2015.56177

[9] Ninomiya, E., Kizaki, T. (1969). Bacterial polysaccharide from Bacillus polymyxa No. 271. Angewandte Makromolekulare Chemie, 6 (1), 179-185. doi: https://doi.org/10.1002/apmc.1969.050060118

[10] Bradbeer, J. F., Hancocks, R., Spyropoulos, F., Norton, I. T. (2015). Low acyl gellan gum fluid gel formation and their subsequent response with acid to impact on satiety. Food Hydrocolloids, 43, 501-509. doi: https://doi.org/10.1016/j.foodhyd.2014.07.006

[11] Drobot, V. I. (2015). Tekhnokhimichnyi kontrol syrovyny ta khlibobulochnykh i makaronnykh vyrobiv. Kyiv, «KondorVydavnytstvo», 972. 